\title{
MicroRNAs: Synthesis, Gene Regulation and Osteoblast Differentiation
}

\section{S. Vimalraj and N. Selvamurugan*}

Department of Biotechnology, School of Bioengineering, SRM University, Kattankulathur 603 203, Tamil Nadu, India

\begin{abstract}
The central dogma of transfer of genetic information from DNA to protein via mRNA is now challenged by small fragment of non coding RNAs typically 19-25 nucleotides in length namely microRNAs (miRNAs). miRNAs regulate expression of the protein coding genes by interfering in their mRNAs and, thus, act as key regulators of diverge cellular activities. Osteoblast differentiation, a key step in skeletal development involves activation of several signalling pathways including TGF $\beta$, BMP, Wnt and transcription factors, which are tightly regulated by miRNAs. In this review, we provide information on recent developments of the synthesis and gene regulation of miRNAs as well as the potential nature of miRNAs that regulate mesenchymal stem cell towards osteoblast differentiation for therapeutic purpose.
\end{abstract}

\section{Introduction}

MicroRNAs (miRNAs) are small endogenous RNAmolecules (19-25 nt) that govern gene expression by targeting mRNAs at posttranscriptional level. lin- 4 was first identified miRNA in nematode. It was produced as shorter transcripts that regulates lin-14 gene coding for nuclear protein through an antisense RNA-RNA interaction (Lee et al., 1993). More than thousands of miRNAs have been found and the search for more miRNAs is still continued. miRNAs are able to control diverse biological process including cell growth, apoptosis, development, metabolism, stress adaptation, hormone signalling and differentiation (Kloosterman and Plasterk, 2006; Bushati and Cohen, 2007; Gangaraju and Lin, 2009; Brodersen and Voinnet, 2009). It is speculated that more than $60 \%$ of human genes coding for proteins possess miRNA binding sites within their $3^{\prime}$ untranslated regions (UTRs). Most importantly, it has been reported that one third of human genes are regulated by miRNAs (Davis and Hata 2009). Animals that unable to produce certain mature miRNAs fail to survive and reproduce, and even a single miRNA malfunction accounts for higher risks of cancer (Wienholds et al., 2003; Costinean et al., 2006). Computational and experimental approaches indicate that a single miRNA can regulate expression of several genes and expression of a single gene can be controlled by several miRNAs (Selbach et al., 2008).

Mesenchymal stem cells (MSCs) are multipotent in nature and are the excellent candidates for cell-based therapeutic strategies to regenerate injured or damaged

*Corresponding author: selvamurugan.n@ktr.srmuniv.ac.in, selvamn2@yahoo.com tissue. They have the potential to undergo multilineage differentiation, such as osteoblasts, chondrocytes, adipocytes, and myoblasts. Regulation of differentiation of MSCs into osteogenic lineage is critical for maintaining bone mass and is necessary for prevention of bone related diseases. It is now evident that osteoblast differentiation is tightly controlled by several regulators including miRNAs (Abdallah and Kassem, 2008; Guo et al., 2008; Lian et al., 2012), and miRNAs can regulate expression of genes during differentiation of MSCs towards osteoblastic cells, resulting in bone formation (Taipaleenma"ki et al., 2012). In the current review we discuss and summarize miRNAs' synthesis including their genomic position, target recognition, and gene regulation, and control of MSCs differentiation into osteoblasts by miRNAs for therapeutic purpose.

\section{Genomic position of miRNAs}

In humans, miRNA genes are present in all chromosomes except $Y$ chromosome (Kim, 2005) but computational studies show that two miRNA genes are positioned in human $\mathrm{Y}$ chromosomal pseudoautosome region (Yuan et al., 2011). Calin et al., (2004) described that human miRNA genes often located at fragile sites and chromosomal regions that involve in the development of various cancers. About half of the miRNAs are discovered in clusters and are transcribed as polycistronic primary transcripts. In the cluster of miRNAs, they may be related to each other by functionally i.e. a set of miRNAs regulates a single metabolic pathway or a single gene or they may contain unrelated miRNAs (Lagos-Quintana et al., 2001; Kim et al., 2006). Majority of mammalian miRNA genes are located in defined transcription units (Kapinas and Delany, 2011). In mammalian genome, introns contain $73 \%$ of miRNAs in which intronic miRNAs in protein coding transcription units are $56 \%$, and intronic miRNAs in non coding transcription units are $17 \%$. The exonic miRNAs in non coding transcription units are found to be $19 \%$. In some cases depending on alternative splicing, $8 \%$ of miRNAs are found in an exon, an intron or mixed (Rodriguez et al., 2004). Saini et al., (2007) described that approximately half of the miRNAs genes are located in non-protein-coding transcripts and the remaining miRNAs are predominantly located in introns of coding genes. Kim et al., (2009) described genomic location of miRNAs: miR-985 located in exonic protein coding CACNG8 gene, miR-155 located exonic non-coding BIC gene, miR-25, miR-93 and miR-106b cluster located in intronic protein coding MCM7 (minichromosome maintenance complex component 7) gene and miR-15a and miR-16-1 cluster located in intronic non-coding DLEU2 (deleted in lymphocytic leukemia 2) gene. In general, miRNAs located in introns which are coincidentally transcribed along with their host genes. Even though miRNAs may be intergenic and intronic, there are no differences either in their structural or thermodynamic parameters (Posrednik et al., 2011). 


\section{Biogenesis of miRNAs}

Transcription of the miRNA gene is mediated by RNA polymerase II (pol II) which also involves in transcription of other mRNAs (Lee et al., 2004). Ozsolak et al., (2008) suggested that many characteristics of protein coding gene promoters were found to be similar as seen in miRNA coding genes such as the relative frequencies of $\mathrm{CpG}$ islands, TFIIB recognition, TATA box, initiator elements and histone modifications. Other RNA polymerases might also be involved in the transcription of miRNA genes because most of smaller sized RNAs like tRNAs, $5 \mathrm{~S}$ rRNAs are transcribed by polymerase III (pol III). For instance, in herpesviruses, cluster of miRNAs are transcribed by pol III (Pfeffer et al., 2005). Another example is that miRNAs encoded by the largest human miRNA cluster, C19MC, is transcribed by pol III (Borchert et al., 2006).

miRNAs are transcribed as long primary transcripts (pri-miRNAs) and they contain several long kilobases of nucleotides with local fold back structure recognized by the nuclear RNase III enzyme Drosha, and its cofactor

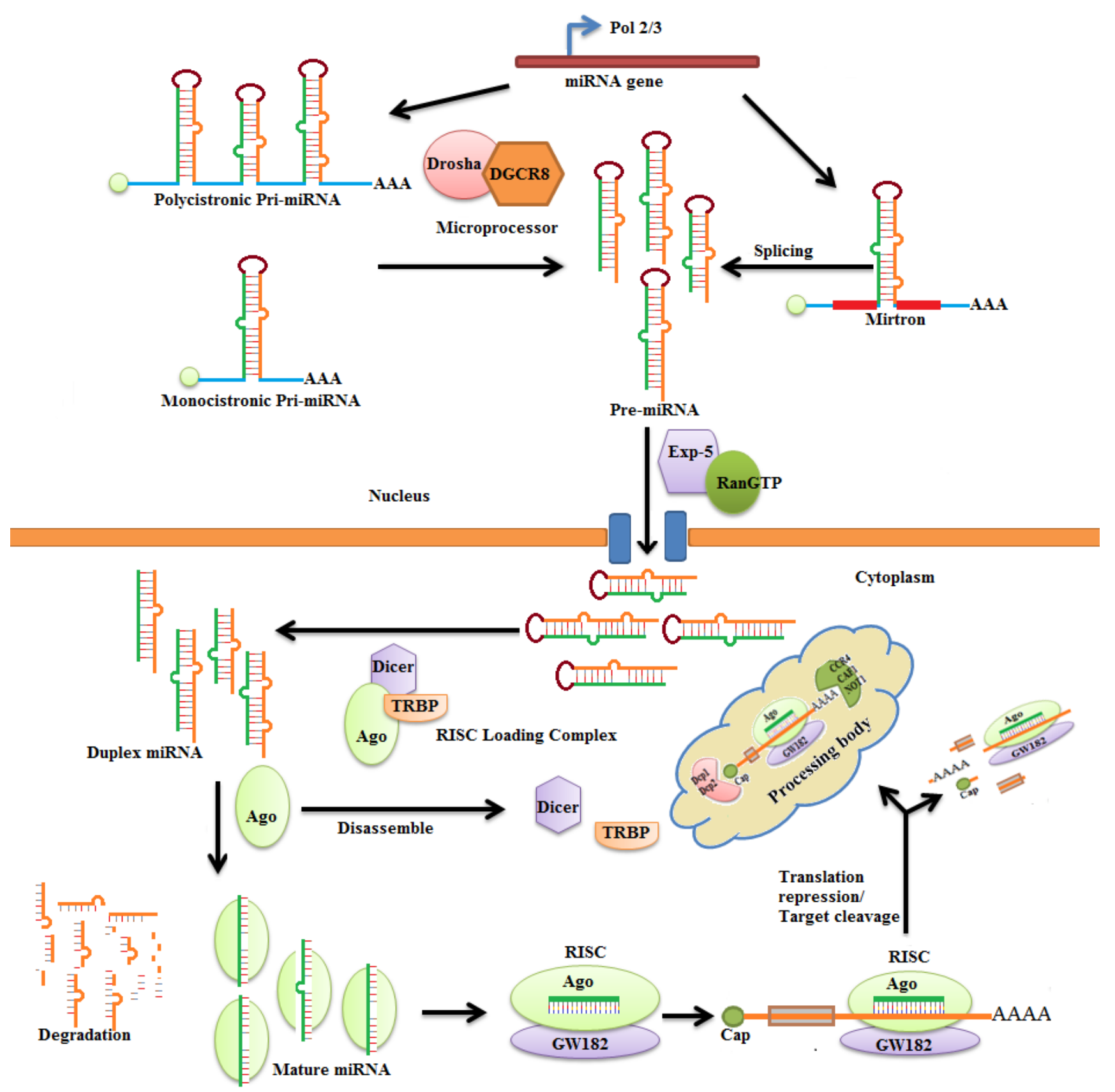

Figure 1. Schematic representation of miRNA biogenesis pathway. Initially miRNAs are transcribed as pri-miRNAs by pol II/III, which are recognised by microprocessor (Drosha+DGCR8) complex to generate pre-miRNA. Exp-5 with its cofactor RanGTP mediates transport of pre-miRNA to cytoplasm where they are again recognised by RLC (Dicer +TRBP+Ago) for further maturation of miRNA. Matured miRNA gets assembled with RISC complex with the help of Ago protein which regulates gene expression upon biding at the $3^{\prime}$ end of mRNA. 
DGCR8 (DiGeorge syndrome critical region gene 8) (Kim, 2005) (Figure 1). These complexes of proteins are known as microprocessor complex which trim the primiRNA to produce shorter hairpin of approximately 70 nucleotides in length as precursor miRNA (pre-miRNA) with a characteristic two nucleotides overhang at the 3 ' end. The trimmed (shredded) ends which flank the premiRNA are likely to be degraded in the nucleus itself due to its instability (Lee et al., 2003). Drosha forms two different mixtures of complexes for processing of pri-miRNAs. A small microprocessor complex that contains only Drosha and DGCR8 processes many pri-miRNAs, and a larger complex that contains double-stranded RNA binding proteins, RNA helicases, heterogeneous nuclear ribonucleoproteins and Ewing's sarcoma proteins processes specific pri-miRNAs (Gregory et al., 2004). Drosha, in addition to containing RNase III domain may require cofactor for its activity because purified Drosha failed to efficiently produce premiRNAs in vitro (Han et al., 2004). Drosha is a conserved large protein $(\sim 160 \mathrm{kDa})$ in animals. It contains two tandem RIIIDs (RNase III domains) and dsRBD (double-stranded RNA-binding domain). dsRBD is known to facilitate Drosha for its substrate recognition. The mid region of the Drosha protein, adjacent to the RIIIDs, is also indispensable for primiRNA processing (Denli et al., 2004; Kim, 2005). Introns with the appropriate size can form a hairpin resembling a pre-miRNA and bypass Drosha cleavage. They are further processed in the cytoplasm by Dicer and these types of miRNAs are named as mirtrons (Ruby et al., 2007) (Figure 1). Exportin-5 (Exp5), a nuclear export factor, recognizes and transports the pre-miRNAs to cytoplasm with the help of Ran-dependent nuclear transport receptors. Pre-miRNAs are stabilized through their interaction with Exp5 (Yi et al., 2003). This is possible by recognition of Exp5 with minihelix motif found in pre-miRNA stem-loops, which typically comprise of stem of $\sim 22$ base pairs, a terminal loop and a $3^{\prime}$ overhang of $\sim 2$ nucleotides (Zeng and Cullen, 2004). This 3 ' overhang of $\sim 2$ nucleotides may indicate Drosha cleaved pre-miRNA.

In cytoplasm, pre-miRNA is processed to become mature miRNA and is assembled with RISC (RNA-Induced Silencing Complex). These are mediated by the RISC loading complex (RLC). RLC is a multi-protein complex composed of RNase Dicer, double-stranded RNA-binding domain proteins, TRBP (Tar RNA Binding Protein) and PACT (protein activator of PKR), and Argonaute-2 (Ago2). TRBP and PACT are not essential for Dicer-mediated cleavage of the pre-miRNA but they participate in the recruitment of Ago2 (Gregory et al., 2005; Haase et al., 2005; Chendrimada et a., 2005; Lee et al., 2006). Dicer can process the duplex premiRNAs without cofactor (Jaskiewicz and Filipowicz 2008). RNase III Dicer along with its cofactors (TRBP, PACT) cleaves the pre-miRNA loop to yield a 19-25 nucleotides duplex miRNA with two nucleotides overhangs at each $3^{\prime}$ end (Ketting et al., 2001). Once the pre-miRNA loop is cleaved, the Dicer and its cofactors disassemble from the site. The cleaved double stranded product (duplex miRNA) possesses two strands namely the functional guide strand or matured miRNA and the passenger strand. The functional strand along with Ago protein (RISC complex) involves in gene silencing functions, while the passenger strand is degraded due to its unstable nature (Treiber et al., 2012). In addition, various helicases and Ago2 proteins are also involved in the process of unwinding the duplex miRNA and activation of RISC (Winter et al., 2009; Bossé and Simard, 2010). RISC is the cytoplasmic effector machine contains a single-stranded miRNA guiding its target mRNAs. Among the two strands only one strand becomes mature miRNA on the basis of thermodynamic asymmetry rule i.e the weakest or less stable $5^{\prime}$ end base pairing is selected as the mature miRNA (Khvorova et al., 2003). The helicase domain of Dicer acts as a sensor for the thermodynamic asymmetry, permitting incorporation of the matured miRNA into RISC. (Noland et al., 2011; Treiber et al., 2012).

\section{Gene target recognition of miRNAs}

miRNAs target mRNAs by complementary base-pairing to multiple sites in 3' untranslated regions (UTRs), and the 5' end of miRNA nucleotides of 2 to 8 is called as seed region (Lewis et al., 2005) (Figure 1). The base-pairing at the 5' end of miRNAs is critical as well as the key for target recognition (Brennecke et al., 2005; Brodersen and Voinnet, 2009). Few reports documented that miRNAs can also target at 5'UTRs of mRNA and protein coding regions (Lytle et al., 2007; Lee et al., 2009). The centre region of miRNA enables to target genes sequence (Shin et al., 2010). In general, most of the targeted mRNAs had interaction with miRNAs through their 3'UTRs (Pasquinelli, 2012). Based on the degree of complementary, mRNA is directed to either destruction by cleavage of its phosphodiester bonds or inhibition by miRNA, for instance perfect or near perfect complementary goes for destruction which is rare in mammalian cells and partial complementary leads to destruction or inhibition of mRNA expression (Pillai, 2005; Brodersen and Voinnet, 2009; Guo et al., 2010; Treiber et al., 2012) (Figure 1). TargetScan (http://www.targetscan.org/) and PicTar (http:// pictar.mdc-berlin.de/) are the commonly available online softwares to predict the computational targets for the miRNAs based on their seed sequences to complimentary of 3'UTRs of target genes.

\section{Mechanism of gene regulation by miRNAs}

In general, protein synthesis occurs in three steps namely, initiation, elongation and termination. Initiation involves recognition of the 5 'cap by proteins called initiation factors in which at least 10 initiation factors are involved like elF4G (large multidomain protein act as a scaffold for assembly of the translational initiation complex), elF4A (an RNA helicase), elF4E, elF3 (recruit $40 \mathrm{~S}$ ribosome), elF6 (60S subunit biogenesis and subunit joining). elF4G is also essential for the interaction with polyadenylate-binding protein 1 (PABP1). elF4G interacts simultaneously with elF4E and PABP1 and brings the two ends of the mRNA in close proximity. This 'circularization' stimulates translational initiation by increasing the affinity of elF4E for m7GpppN (Wells et al., 1998; Nilsen, 2007; Filipowicz et al., 2008). elF4G interaction with elF3 resulting recruitment of the $40 S$ subunit. This subunit consequently identifies the start codon, and in association with large ribosomal subunit initiation of translation takes place.

Initiation is followed by elongation in which mRNA is occupied by several actively elongating ribosomes constituting a polysome. The elongation step can also be regulated by phosphorylation of the elongation factor eEF2. As translation proceeds, newly synthesized proteins (nascent polypeptides) emerge from the large ribosomal 
subunit. Once ribosome encounters the stop codon, termination occurs. The ribosome is dissociated from the mRNA, and the completed protein is released. Initiation of some cellular mRNAs is independent of $\mathrm{m} 7 \mathrm{G}$ cap and eIF4E. During this mode of translation, ribosomes are recruited by
mRNA through interaction with the internal ribosome entry sites (IRES), which are highly structured regions in the $5^{\prime}$ UTR (Jackson, 2005; Filipowicz et al., 2008; Eulalio et al., 2008).

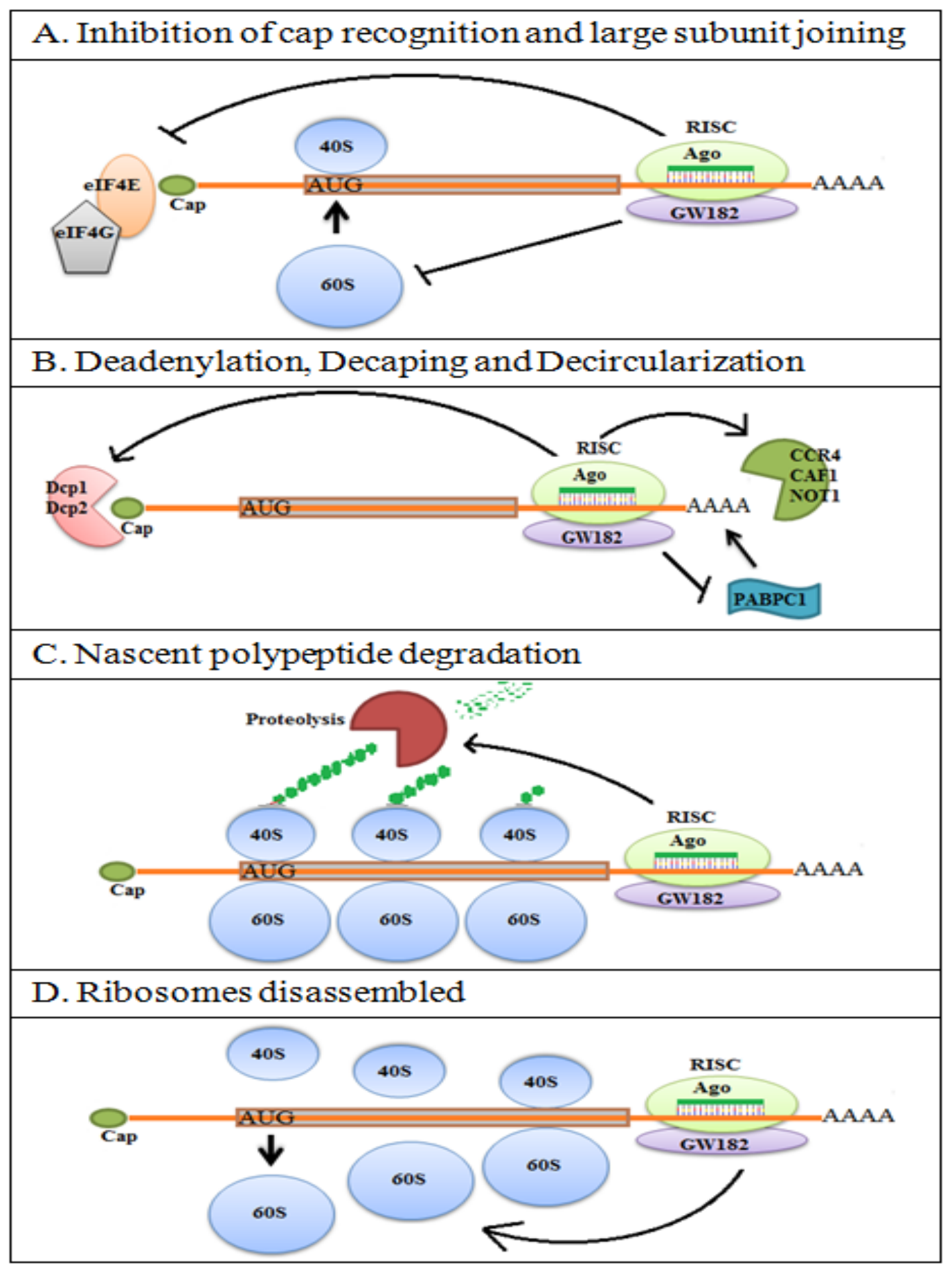

Figure 2. Mechanisms of miRNA mediated gene regulation.

A. Blocking of cap recognition by inhibition of initiation factor of translation and inhibition of joining of large ribosomal subunit by Ago protein of RISC complex.

B. Decaping by Dcp1 and Dcp2 enzymes and denadenylation by CCR4, CAF1 and deciucularization by NOT1 complex.

C. Newly synthesized polypeptides degraded by the process of RISC complex induced proteolysis.

D. Premature termination of ribosomes in IRES translation. 
Generally, miRNAs inhibit protein synthesis either by repressing the translation or by deadenylation and subsequent degradation of mRNA targets. However evidence shows that some miRNAs can up regulate translation (Vasudevan et al., 2007). miRNAs mediated mRNA degradation requires Argonaute proteins, the Processing body ( $P$ body) component which consists of GW182, deadenylase complex (CAF1, CCR4, NOT1), decapping enzyme Dcp2, and several decapping activators including Dcp1, Ge-1, EDC3, and RCK/p54 (P bodies, also known as GW bodies) (Behm-Ansmant et al., 2006; Eulalio et al., 2007) (Figure 2). Apart from the P bodies, Gibbings et al., (2009) found another complex called multivesicular bodies (MVBs) that associate with components of miRNA effector complexes and modulate miRNA activity. Chendrimada et al., (2007) reported that miRNAs inhibit mRNA translation in the initiation steps. Ago2 associates with both elF6 and large ribosomal subunits and consequently prevents them joining with the small ribosomal subunit (Figure 2A). Thus, if Ago2 recruits elF6, then the large and small ribosomal subunits are unable to associate as 805 ribosomal complex, causing repression of translation. miRNAs control translation initiation by inhibiting elF4E/cap and poly(A) tail function (Humphreys et al., 2005; Filipowicz et al., 2008). The repressed complexes move to $P$ bodies for further mRNA storage or degradation (Pillai, 2005).

Upon binding of miRNA to mRNA at 3' UTR induces deadenylation and followed by decapping of target mRNAs. $P$ body component GW182 recruits miRNA targets through direct interactions with the Argo proteins, contributing translational repression. This includes mRNA deadenylation by the deadenylase complex (CAF1, CCR4, NOT1) and mRNA decapping by the decapping complex (Dcp1, Dcp2), and exonucleolytic degradation by exonuclease Xrn1 (Behm-Ansmant et al., 2006; Eulalio et al., 2007) (Figure 2B). Degradation of nascent polypeptide by miRNAs can also occur via proteolysis, for instance an observation showed that even though polyribosomes were actively involved in translation, the nascent polypeptide chain could not be detected by immunoprecipitation implying repression of protein accumulation due to cotranslational protein degradation (Nottrott et al., 2006; Fabian et al., 2010) (Figure $2 \mathrm{C})$. In the case of mRNA recruiting ribosomes through IRES translation process, miRNA inhibition can still occur at post initiation step, for instance Petersen et al., (2006) demonstrated that miRNAs block translation elongation by promoting premature termination and following ribosome disassemble (Olsen and Ambros, 1999) (Figure 2D).

Role of miRNAs in differentiation of MSCs to osteoblasts Mesenchymal stem cells (MSCs), isolated from bone marrow, cord blood, peripheral blood, fallopian tube, fetal liver and lung, have the ability to self-renewal and differentiate into multiple cell lineages and they have significant clinical potential in cellular therapies for tissue regeneration. Bone marrow derived MSCs have the functional properties such as extensive proliferation and ability to differentiate into osteoblasts, chondrocytes, adipocytes, cartilage, tendons, muscle, and skin. MSCs differentiation into osteoblasts is critical for maintenance of bone remodelling that involves bone formation and bone resorption. In this regard, differential expression of miRNAs has a major impact on regulation of osteoblast differentiation (Bianco et al., 2001;
Abdallah et al., 2008; Inosea et al., 2009). Hence, in the following sections, an insight into miRNAs participation in osteoblast differentiation is emphasised. Figure 3 summarizes miRNAs that positively or negatively regulate osteoblast differentiation and those miRNAs and their target genes are shown.

(i) miRNAs involved in inhibition of osteoblast differentiation

There are several miRNAs which have been reported to inhibit osteoblast differentiation for regulation of bone remodeling. This physiological regulation brought out by miRNAs could be important for balancing bone formation and bone resorption processes. For example, miR-206 expression is correlated with osteoblast differentiation. Overexpression of miR-206 in osteoblasts inhibit their differentiation and connexin 43 (Cx43), a major gap junction protein in osteoblasts is found to be a target gene for miR206 (Inosea et al., 2009). Kahai et al., (2006) demonstrated that miR-378 decreases expression of nephronectin (NN, an extracellular matrix protein) resulting inhibition of osteoblast differentiation. It was found that NN 3'-UTR contains a binding site for miR-378. When NN was overexpressed, osteoblast differentiation and bone nodule formation were enhanced by mediating the involvement of EGF-repeat functioning and Erk signalling. miR-138 was shown to inhibit osteoblast differentiation by targeting FAK (Focal Adhesion Kinase) translation, consequently reduced phosphorylation of FAK and its target ERK1/2 proteins resulting decrease of Runx2 phosphorylation and Osterix expression (Eskildsen et al., 2011).

Runx2, a bone specific transcription factor regulates several genes and is required for expression of several osteoblast differentiation genes such as type I collagen, osteocalcin (Selvamurugan et al., 2006). Runx2 gene expression is inhibited by miR-204 and miR-211, thus acting as negative regulators of osteoblast differentiation and mineralization in mesenchymal progenitor cells and bone marrow stromal cell (BMSCs) (Huang et al., 2010). There are several miRNAs namely miR-23a, miR-30c, miR-34c, miR-133a, miR-135a, miR-137, miR-204, miR205, miR-217, and miR-338 that can target and decrease expression of Runx2 protein resulting inhibition of osteoblast differentiation (Hassan et al., 2010; Zhang et al., 2011). miR-355 was found to be directly targeting Runx2 mRNA, and overexpression of miR-335 in hMSCs inhibits their proliferation and migration, as well as their osteogenic and adipogenic potential (Tome et al., 2011).

TGF- $\beta$ /BMP signalling pathways and their components are essential for activation of genes involved in osteoblast differentiation. MSCs differentiation into osteoblasts can be inhibited by miRNAs such as hsa-miR-31, hsa-miR-106a, hsa-miR-148a, and hsa-miR-424 and their target genes were found to be as Runx2, Cbfb, BMPs. miR-133 and miR135 were found to inhibit differentiation of osteoprogenitors through attenuating Runx2 and Smad5 pathways, respectively which are synergistically involved in bone formation (Li et al., 2008). miR-26a has been shown to inhibit osteoblast differentiation by targeting Smad1 in human adipose tissue derived stem cells (Luzi et al., 2008). Smad proteins are intracellular signalling components for TGF- $\beta$ / BMP signalling and BMP-2 via Smads activates osteoblast essential genes (Kwok et al., 2009). Yin et al., 2010 have 
shown that miR-155 targets the BMP signalling cascade, including SMAD1, SMAD5, HIVEP2, CEBPB, RUNX2, and MYO10 in lung epithelial cells. Expression of miR-141 and miR-200a down regulated BMP-2-induced pre-osteoblast differentiation through the translational repression of DIx5 (Distal-less homeobox 5). Dlx5 is a transcription factor that participates in pre-osteoblast differentiation. BMP-2 regulates Osterix expression by mediating DIx5 (Lee et al., 2003; Itoh et al., 2009), and Osterix is also responsible for expression of osteoblast differentiation genes (Kwok et al., 2009).

Gao et al., (2011) have reported that during differentiation of MSCs derived from bone marrow into osteoblasts, there are specific miRNAs that are either under expressed or over expressed. The four under expressed miRNAs (hsa-miR-31, hsa-miR-106a, hsa-miR-148a and hsa-miR-424) in osteo-differentiated MSCs have been predicted to target the mRNAs of genes such as Runx2, CBFB, and BMPs, which are involved in bone formation; whereas hsa-miR-30c, hsa-miR-15b and hsa-miR-130b which are over expressed in osteo-differentiated MSCs have been predicted to target MSC markers such as CD44, ITGB1, and FLT1, stemness-maintaining factor (FGF2 and CXCL12), and genes involved in inhibition of osteogenesis such as BMPER, CAMTA1, and GDF6. hsa-miR-148b, hsamiR-27a and hsa-miR-489 have been shown to be involved in regulation of osteogenesis. hsa-miR-27a and hsamiR-489 have been shown to down-regulate differentiation through repression of GCA (grancalcin), PEX7 (peroxisomal matrix enzymes), APL (liver/bone/kidney-specific alkaline phosphatase) while hsa-miR-148b has been shown to up-regulate osteoblast differentiation. Expression of these miRNAs can be modulated to induce osteogenesis in the absence of other external differentiation cues and restored osteogenic potential in high passage number in human MSCs (Schoolmeesters et al., 2009).

(ii) miRNAs involved in promoting osteoblast differentiation

Even though several miRNAs inhibit MSCs or osteoprogenitors for differentiation, there are miRNAs that positively regulate osteoblast differentiation. miR-218 has been shown to facilitate osteoblasts to differentiate into the final stage of forming mineralized tissue by inhibiting ERB1 (TOB1) and sclerostin (SOST) (Jafferji, 2009). As we mentioned earlier, activation of the TGF/BMP/Wnt signalling and their components could take part a major role for differentiation of MSCs towards osteoblasts and these events are regulated by miRNAs. miR-2861 promotes BMP2induced ST2 osteoblast differentiation by repressing histone deacetylase 5 (HDAC5) expression (Li et al., 2009). Runx2 protein, a bone specific transcription factor is susceptible

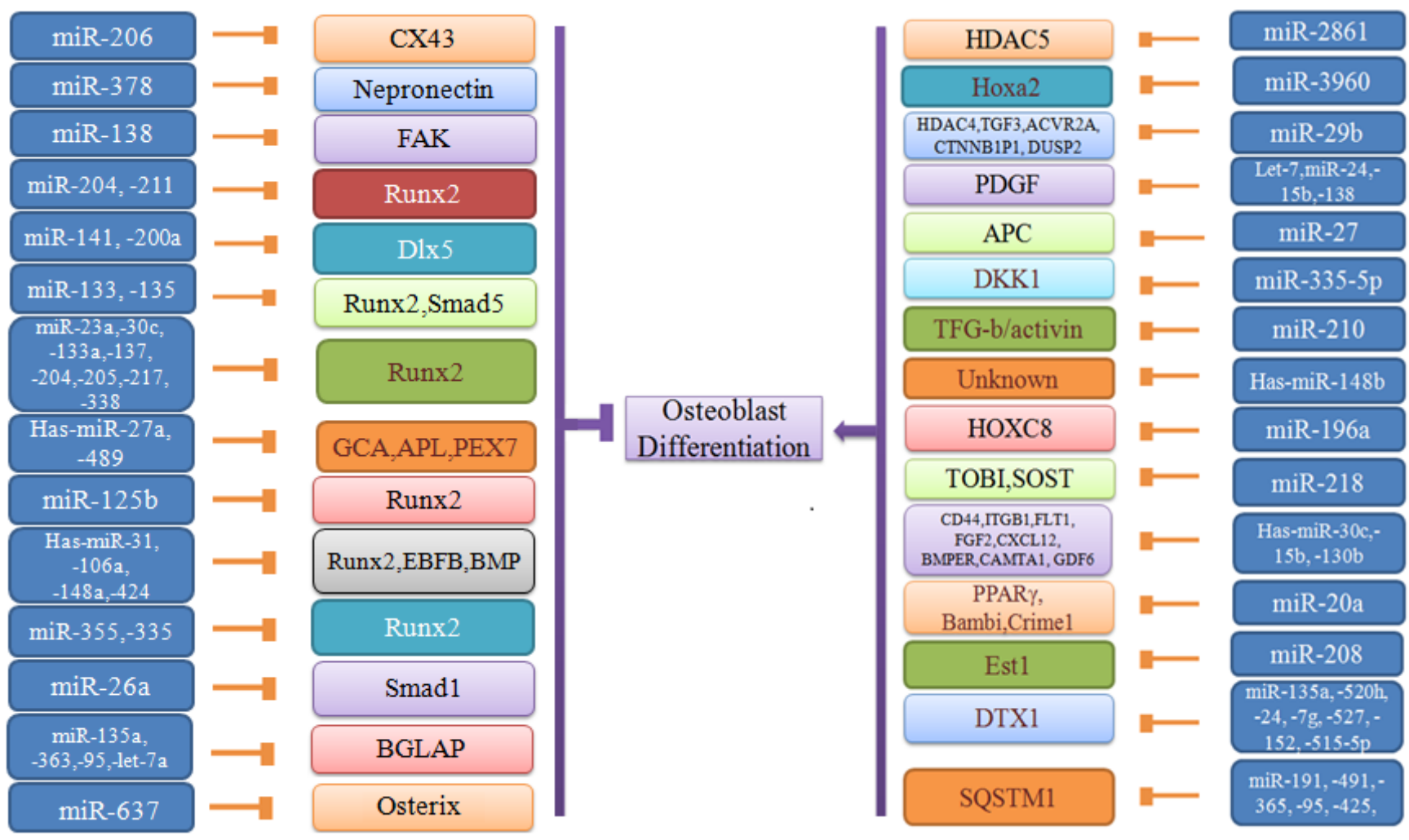

\footnotetext{
$\Rightarrow$ Inhibiton of osteoblast differentiation _ Promote osteoblast differentiation
}

Figure 3. miRNAs in osteoblast differentiation. miRNAs that participate in stimulation or inhibition of osteoblast differentiation and their target genes are represented. 
to degradation by Smurf (Smad ubiquitin regulatory factor) mediated ubiquitination pathway and thus, Runx2 stability is important for regulation of osteoblast differentiation. BMP-2 stimulates acetylation of Runx2 protein by $p 300$ resulting inhibition of Smurf1-mediated degradation of Runx2 and increases the Runx2 transactivation activity. HDAC4 and HDAC5 proteins can deacetylate Runx2 protein, and thus Runx2 protein is vulnerable to Smurf-mediated degradation (Jeon et al., 2006). Homeobox A2 (Hoxa2), a repressor of Runx2 is targeted by miR-3960 leading to enhanced osteogenesis in BMP-2 induced ST2 stromal cells. Overexpression of Runx2 induces miR-3960 and miR-2861 transcription together from the same miRNA polycistron and both are involved in osteoblast differentiation through a regulatory feedback loop of Runx2/miR-3960/miR-2861(Hu et al., 2011).

Inhibitors of osteoblast differentiation such as HDAC4, TGF3, ACVR2A, CTNNBIP1, and DUSP2 are down regulated by miR-29b, resulting in promotion of osteogenesis ( $\mathrm{Li}$ et al., 2009). Increased levels of let-7, $\mathrm{miR}-24, \mathrm{miR}-125 \mathrm{~b}$, and miR-138 are predicted to repress the expression of non osteogenic target mRNAs involved in platelet-derived growth factor (PDGF) pathway, and these miRNAs enhance osteogenic differentiation (Goff et al., 2008). miR-27 promotes osteoblast differentiation by inhibiting adenomatous polyposis coli (APC) gene expression, consequently activates Wnt signalling through accumulation of $\beta$-catenin. In the absence of activation of Wnt signalling, $\beta$-catenin is degraded through sequential phosphorylation by the destruction complex which is composed of APC, axin, glycogen synthase kinase 3 beta (GSK3 $\beta$ ), and casein kinase I (CKI). During activation of Wnt signalling, phosphorylation of $\beta$-catenin by GSK3 $\beta$ is inhibited which causes accumulation non-phosphorylated $\beta$-catenin in cytoplasm then it translocates into nucleus and associates with TCF/LEF family of transcriptional factors and induces target gene expression. Hence, inhibition of APC through miR-27 ultimately leads to accumulation of

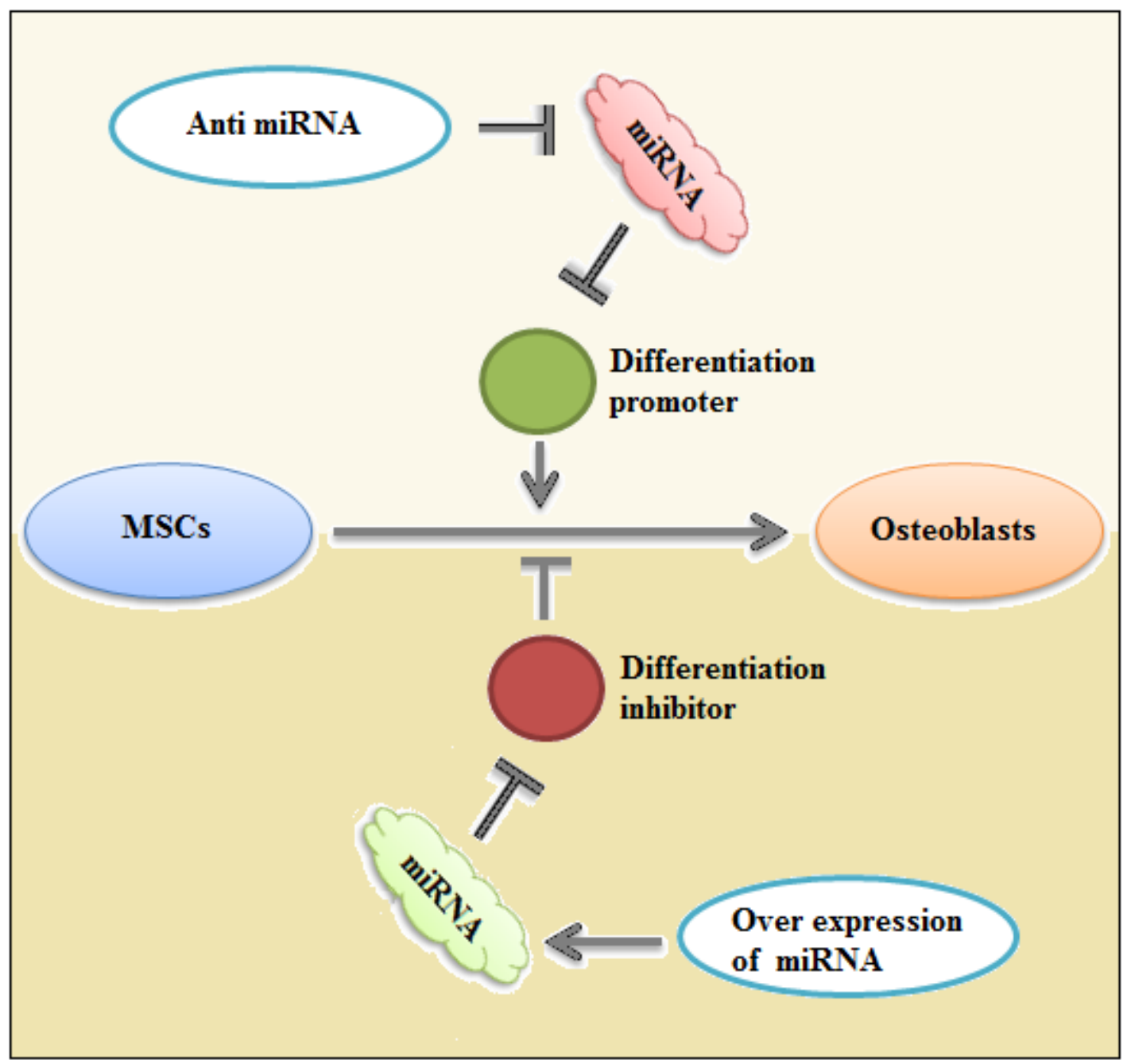

Figure 4. Schematic diagram of manipulation of miRNAs activity. Anti miRNA inhibits the miRNA that targets promoter protein coding genes of osteoblast differentiation. Over expression of miRNA enhances the miRNA activity to target inhibitor protein coding genes of osteoblast differentiation. 
$\beta$-catenin and activates Wnt singlaing (Wang and Xu, 2010; Lin and Hankenson, 2011). Kapinas et al., (2010) have shown that miR-29a promotes osteoblast differentiation by down regulating the inhibitors of canonical Wnt signalling such as Dkk1, Kremen2, and sFRP2 (secreted frizzledrelated protein). miR-335-5p also enhances osteogenic differentiation by activating Wnt signaling through inhibition of Dickkopf-related protein 1 (DKK1). DKK1 has the property antagonistic to canonical Wnt signalling by binding with LRP5/6 receptors. The Wnt pathway is activated by binding of Wnt protein to the transmembrane receptor Frizzled (Fzd) and co-receptor LRP5/6 proteins by the protein kinase activity of GSK3 $\beta$, followed by the increased levels of nonphosphorylated $\beta$-catenin (Zhang et al., 2011).

AcvR1b is a type I receptor and is activated by the TGF- $\beta$ /activin signalling resulting in inhibition of expression of osteoblast differentiation genes through phosphorylation of receptor-regulated Smads (R-smad) (Maeda et al., 2004). In the case of miR-210, it acts as a positive regulator of osteoblastic differentiation by inhibiting the TGF- $\beta$ /activin signalling pathway through inhibition of AcvR1b (Mizuno et al., 2008). In BMP signalling, BMP stimulates activation of BMP receptor, causing phosphorylation of Smad1. The phosphorylated Smad1 translocates to nucleus regulating gene expression by binding with nuclear transcriptional factor or by directly binding with DNA. Overexpression of miR-196a in human adipose tissue derived MSCs enhanced osteogenic differentiation and this effect is mediated through its predicted target HOXC8. HOXC8, a transcriptional repressor interacts with Smad1 thereby prevents the interaction of Smad1 with DNA resulting in the suppression of Smad1 mediated genes involved in osteoblast differentiation (Hullinger et al., 2001; Kim et al., 2009). miR-208 enhances BMP2 induced pre-osteoblast differentiation by targeting $\mathrm{V}$-ets Erythroblastosis Virus E26 oncogene Homolog 1 (Ets1) gene, which results in transactivation of osteopontin, Runx2, type I procollagen and parathyroid hormone-related protein (PTHrP) (Itoh et al., 2010).

miRNAs have the potential to maintain the balance between osteoblast differentiation and adipocyte differentiation. miR-20a stimulates expression of osteoblast regulator and markers such as BMP2, BMP4, Runx2, Osterix, osteocalcin and osteopontin; at the same time it also inhibits expression of adipogenic marker such as PPARy, and Bambi and Crim1 (Zhang et al., 2011). miR637 expression decreases osteoblast differentiation by targeting Osterix transcription factor whereas it increases adipocyte differentiation from hMSCs. Lentiviral over expression of miRNA studies suggested expression level of miR-637 can be correlated with stimulation of inhibition of either osteogenesis or adipogenesis (Zhang et al., 2011). It is mostly suggested that the suppression of adipogenesis may be of considerable significance for the prevention and treatment of bone related diseases such as osteoporosis.

In vitro osteoblastic differentiation of human umbilical cord mesenchymal stem cells (ucMSC) was studied and during that study, a differential expression of miRNAs has been found. At 24 hours of culture period, computational target prediction showed that miR-135a, miR-520h, miR24, let-7g, miR-527, miR-152 and miR-515-5p target DTX1 mRNA involved in inhibition of osteoblast differentiation, hence these miRNAs may promote osteoblast differentiation.
Subsequently at 48 hours of culture period, miR-191, miR449a, miR-491, miR-365, miR-95 and miR-425 target SQSTM1 mRNA involved in NF-kB regulation, hence these set of miRNAs may also promote osteoblast differentiation and finally, in $7^{\text {th }}$ day of cultured cells miR-135a, let-7a, miR-363 and miR-95 target BGLAP mRNA involved in bone differentiation and metabolism, hence these set of miRNAs may involve in inhibition of differentiation (Octacílio-Silva et al., 2010). Thus, there is a sequential expression of set of miRNAs regulating MSCs differentiation into osteoblasts

Microenvironment determines the role of miRNAs for regulation of osteoblast differentiation. Liu et al., (2011) reported that miR-17 has a role for stimulation or inhibition of osteoblast differentiation that depends on the microenvironment. In human periodontitis-affected periodontal ligament tissue-derived mesenchymal stem cells (P-PDLSCs), overexpression of miR-17 increases osteogenic differentiation by increasing expression of alkaline phosphatase, Runx2 and osteocalcin genes through suppression of Smurf1. In healthy human periodontal ligament tissue-derived mesenchymal stem cells (H-PDLSCs), overexpression of miR-17 decreases expression of alkaline phosphatase, Runx2 and osteocalcin. Hence, it is suggested that microenvironment or stromal cells may activate different signalling pathways and that could be regulated by miRNAs leading to regulation of osteoblast differentiation.

\section{miRNAs - therapeutic agent}

To our knowledge till date around 50 miRNAs have been investigated in depth of exact protein coding gene targets and their systemic functions in MSCs differentiation into osteoblasts. The computational target prediction of 3' UTRs suggest that a single miRNA can target more number of protein coding genes involved in osteoblast differentiation as well as a single gene can be targeted by cluster of miRNAs, suggesting an extensive network of the structural and functional properties of miRNAs. So, a careful selection should be made as selecting miRNA for therapeutic agent, without suppressing other desired genes. The two strategies involving miRNAs as therapeutic agent are (1) over expression of miRNAs and (2) over expression of anti miRNAs. Over expression of miRNAs in MSCs could target expression of genes that negatively regulate oseoblast differentiation; where as over expression of anti miRNAs in MSCs could target miRNAs that negatively regulate osteoblast differentiation (Figure 4). Hence, various signalling pathways/transcription factors responsible for osteoblast differentiation can be modulated by miRNAs in MSCs.

\section{Conclusions}

The knowledge of miRNAs targeted gene regulation studies in MSCs and osteoblasts would help to develop novel MSCs based therapeutic opportunities for improving the treatment of bone related diseases. Since expression of miRNAs is either up regulated or down regulated during differentiation of MSCs into osteoblasts, the manipulation of regulation of miRNAs by over expression and anti miRNAs would be possible for promoting new strategy for therapeutic purposes of treating bone diseases especially osteoporosis. Although many more reports have been suggested regulation of miRNAs during differentiation of MSCs into osteoblasts, 
still much more details remain unclear. In future prospectus, bringing the miRNAs to therapeutic or clinical purpose in systems may face many challenges and controversial debate on their specificity of targets, dose, combinations of miRNAs (cluster) and proficient miRNAs or anti miRNAs transfection.

\begin{abstract}
Abbreviations
MiRNAs, microRNAs; MSCs, mesenchymal stem cells; TGF, transforming growth factor; BMP, bone morphogenetic protein, RISC, RNA-Induced Silencing Complex; HDAC, histone deacetylase; GSK3 $\beta$, glycogen synthase kinase 3beta; LIF, leukemia inhibitory factor; sFRP2, secreted Frizzled-Related Protein; AMOs, anti-miRNA oligonucleotides.
\end{abstract}

\section{Acknowledgements}

We thank A. Moorthi and S. Saravanan for their technical help. This work was supported, in part, by the Indian Council of Medical Sciences, India (Grant Nos. 5/13/2009-NCD-III; 80/10/2010-BMS to N.S).

\section{References}

Abdallah, B.M., and Kassem, M. (2008). Human mesenchymal stem cells: From basic biology to clinical applications. Gene Ther. 15, 109-116.

Behm-Ansmant, I., Rehwinkel, J., Doerks, T., Stark, A., Bork, P., and Izaurralde, E. (2006). mRNA degradation by miRNAs and GW182 requires both CCR4:NOT deadenylase and DCP1:DCP2 decapping complexes. Genes Dev. 20, 1885-1898.

Bianco, P., Riminucci, M., Gronthos, S., and Robey, P.G. (2001). Bone marrow stromal stem cells: Nature, biology, and potential applications. Stem Cells 19, 180-192.

Borchert, G.M., Lanier, W., and Davidson, B.L. (2006). RNA polymerase III transcribes human microRNAs. Nature Struct. Mol. Biol. 13, 1097-1101.

Bossé, G. D., and Simard, M. J. (2010). A new twist in the microRNA pathway: Not Dicer but Argonaute is required for a microRNA production. Cell Res. 20, 735-737.

Brennecke, J., Stark, A., Russell, R.B., and Cohen, S.M. (2005). Principles of microRNA-target recognition. PLoS Biol. 3, e85.

Brodersen. P., and Voinnet, O. (2009). Revisiting the principles of microRNA target recognition and mode of action. Mol. cell Bio. 10,141-148.

Bushati, N., and Cohen, S.M. (2007). MicroRNA functions. Annu. Rev. Cell Dev. Biol. 23, 175-205.

Calin, G.A., Sevignani, C., Dumitru, C.D., Hyslop, T., Noch, E., Yendamuri, S., Shimizu, M., Rattan, S., Bullrich, F., Negrini, M., and Croce, C.M. (2004). Human microRNA genes are frequently located at fragile sites and genomic regions involved in cancers. Proc. Natl. Acad. Sci. USA. 101, 2999-3004.

Chendrimada, T.P., Finn, K.J., Ji, X., Baillat, D., Gregory, R.I., Liebhaber, S.A., Pasquinelli, A.E., and Shiekhattar, R. (2007). MicroRNA silencing through RISC recruitment of elF6. Nature 447, 823-828.

Chendrimada, T.P., Gregory, R.I., Kumaraswamy, E., Norman, J., Cooch, N., Nishikura, K., and Shiekhattar, R. (2005). TRBP recruits the Dicer complex to Ago2 for microRNA processing and gene silencing. Nature 436, 740-744.
Costinean, S., Zanesi, N., Pekarsky, Y., Tili, E., Volinia, S., Heerema, N., and Croce, C.M. (2006). Pre-B cell proliferation and lymphoblastic leukemia/high-grade lymphoma in E(mu)-miR155 transgenic mice. Proc. Natl. Acad. Sci. USA. 103, 7024-7029.

Davis, B.N., and Hata, A. (2009). Regulation of MicroRNA Biogenesis: A miRiad of mechanisms. Cell Commun. Signal. 10, 7:18.

Denli, A.M., Tops, B.B., Plasterk, R.H., Ketting, R.F., and Hannon, G.J. (2004). Processing of primary microRNAs by the Microprocessor complex. Nature 432, 231-235.

Eskildsen, T., Taipaleenmäki, H., Stenvang, J., Abdallah, B.M., Ditzel, N., Nossent, A.Y., Bak, M., Kauppinen, S., and Kassem, M. (2011). MicroRNA-138 regulates osteogenic differentiation of human stromal (mesenchymal) stem cells in vivo. Proc. Natl. Acad. Sci. USA. 108, 6139-6144.

Eulalio, A., Behm-Ansmant, I., and Izaurralde, E. (2007). $P$ bodies: at the crossroads of post-transcriptional pathways. Nat. Rev. Mol. Cell. Biol. 8, 9-22.

Eulalio, A., Huntzinger, E., and Izaurralde, E. (2008). Getting to the Root of miRNA-Mediated Gene Silencing. Cell 132, 9-14.

Eulalio, A., Rehwinkel, J., Stricker, M., Huntzinger, E., Yang, S.F., Doerks, T., Dorner, S., Peer Bork, P., Boutros, M., and Izaurralde, E. (2007). Target-specific requirements for enhancers of decapping in miRNA-mediated gene silencing. Genes Dev. 21, 2558-2570.

Fabian, M.R., Sonenberg, N., and Filipowicz, W. (2010). Regulation of mRNA Translation and Stability by microRNAs. Annu. Rev. Biochem. 79, 351-379.

Filipowicz, W., Bhattacharyya, S.N., and Sonenberg, N. (2008). Mechanisms of post-transcriptional regulation by microRNAs: are the answers in sight?. Genetics 9, 102114.

Gangaraju, V.K., and Lin, H. (2009). MicroRNAs: key regulators of stem cells. Nat. Rev. Mol. Cell. Biol. 10, 116125.

Gao ,J., Yang, T., Han, J., Yan, K., Qiu, X., Zhou, Y., Fan, Q., and Ma, B. (2011). microRNA expression during osteogenic differentiation of human multipotent mesenchymal stromal Cells from Bone Marrow. J. Cel. Biochem. 112, 1844-1856.

Gibbings, D.J., Ciaudo, C., Erhardt, M., and Voinnet, O. (2009). Multivesicular bodies associate with components of miRNA effector complexes and modulate miRNA activity. Nat. Cell Biol. 11, 1143-49.

Goff, L.A., Boucher, S., Ricupero, C.L., Fenstermacher, S., Swerdel, M., Chase, L.G., Adams, C.C., Chesnut, J., Lakshmipathy, U., and Hart, R.P. (2008). Differentiating Human Multipotent Mesenchymal Stromal Cells Regulate microRNAs: Prediction of microRNA Regulation by PDGF During Osteogenesis. Exp. Hematol. 36, 1354-1369.

Gregory, R.I., Chendrimada, T.P., Cooch, N., and Shiekhattar, R. (2005). Human RISC couples micro- RNA biogenesis and posttranscriptional gene silencing. Cell 123, 631-640.

Gregory, R.I., Yan, K.P., Amuthan, G., Chendrimada, T., Doratotaj, B., Cooch, N, and Shiekhattar, R. (2004). The Microprocessor complex mediates the genesis of microRNAs. Nature 432, 235-240.

Guo, H., Ingolia, N.T., Weissman, J.S., and Bartel, D.P. (2010). Mammalian microRNAs predominantly act to decrease target mRNA levels. Nature 466, 835-840. 
Guo, L., Zhao, R.C., and Wu, Y. (2008). The role of microRNAs in self-renewal and differentiation of mesenchymal stem cells. Exp. Hematol. 39, 608-616.

Haase, A.D., Jaskiewicz, L., Zhang, H., Lainé, S., Sack, R., Gatignol, A., and Filipowicz, W. (2005). TRBP, a regulator of cellular PKR and HIV-1 virus expression, nteracts with Dicer and functions in RNA silencing. EMBO Rep. 6, 961967.

Han, J., Lee, Y., Yeom, K.H, Kim, Y.K., Jin, H, and Kim, V.N. (2004). The Drosha-DGCR8 complex in primary microRNA processing. Genes Dev. 18, 3016-3027.

Hassan, M.Q., Gordon, J.A., Beloti, M.M., Croce, C.M, van Wijnen, A.J., Stein, J.L., Stein, G.S., and Lian, J.B. (2010). A network connecting Runx2, SATB2, and the miR-23a 27a 24-2 cluster regulates the osteoblast differentiation program. Proc. Natl. Acad. Sci. USA. 107, 19879-19884.

Hu, R., Li, H., Yang, L., Chen, C., Xia, Z.Y., Guo, L.J., Xie, H., Zhou, H.D., Wu, X.P., and Luo, X.H. (2011). A Runx2/ miR-3960/miR-2861 Regulatory Feedback Loop during Mouse Osteoblast Differentiation. J. Biol. Chem. 286, 12328-12339.

Huang, J., Zhao, L., Xing, L., and Chen, D. (2010). MicroRNA-204 Regulates Runx2 Protein Expression and Mesenchymal Progenitor Cell Differentiation. Stem Cells 28, 357-364.

Hullinger, T.G., Pan, Q., Viswanathan, H.L., and Somerman, M.J. (2001). TGFbeta and BMP-2 activation of the OPN promoter: Roles of smad- and hox-binding elements. Exp. Cell Res. 262, 69-74.

Humphreys, D.T., Westman, B.J., Martin, D.I., and Preiss, T. (2005). MicroRNAs control translation initiation by inhibiting eukaryotic initiation factor 4E/cap and poly(A) tail function. Proc. Natl. Acad. Sci. USA. 102, 1696116966.

Inosea, H., Ochi, H., Kimura, A., Fujita, K., Xu, R., Sato, S., Iwasaki, M., Sunamura, S., Takeuchi, Y., Fukumoto, S., Saito, K., Nakamura, T., Siomi, H., Ito, H., Arai, Y., Shinomiya, K., and Takeda, S. (2009). A microRNA regulatory mechanism of osteoblast differentiation. Proc. Natl. Acad. Sci. USA. 106, 20794-20799.

Itoh, T., Nozawa, Y., and Akao, Y. (2009). MicroRNA-141 and -200a Are Involved in Bone Morphogenetic Protein2-induced Mouse Pre-osteoblast Differentiation by Targeting Distal-less Homeobox 5. J. Biol. Chem. 284, 19272-19279.

Itoh, T., Takeda, S., and Akao, Y. (2010). MicroRNA-208 modulates BMP-2-stimulated mouse preosteoblast differentiation by directly targeting $\mathrm{V}$-ets erythroblastosis virus E26 oncogene Homolog 1. J. Biol. Chem. 285, 27745-27752.

Jackson, R.J. (2005). Alternative mechanisms of initiating translation of mammalian mRNAs. Biochem. Soc. Trans. 33, 1231-1241.

Jafferji, M. (2009). Regulation of osteoblast differentiation by microRNAs. Umass medical school. MQP-BIODSA-7214.

Janet, B., and Amir, H. (2008). Therapy analysis-microRNA; update analysis, Pharmaprojects 29.

Jaskiewicz, L., and Filipowicz, W. (2008). Role of Dicer in posttranscriptional RNA silencing. Curr. Top. Microbiol. Immunol. 320, 77-97.

Jeon, E.J., Lee, K.Y., Choi, N.S., Lee, M.H., Kim, H.N., Jin, Y.H., Ryoo, H.M., Choi, J.Y., Yoshida, M., Nishino, N.,
Oh, B.C., Lee, K.S., Lee, Y.H., Bae, S.C. (2006). Bone Morphogenetic Protein-2 Stimulates Runx2 Acetylation. J. Biol. Chem. 281, 16502-16511.

Kahai, S., Lee, S.C., Lee, D.Y., Yang, J., Li, M., Wang, C.H., Jiang, Z., Zhang, Y., Peng, C., and Yang, B.B. (2006). MicroRNA miR-378 Regulates Nephronectin Expression Modulating Osteoblast Differentiation by Targeting GalNT-7. PLoS One 4, e7535.

Kapinas, K., and Delany, A.M. (2011). MicroRNA biogenesis and regulation of bone remodeling. Arthritis Res. Ther. 13, 220.

Kapinas, K., Kessler, C., Ricks, T., Gronowicz, G., and Delany, A.M. (2010). miR-29 modulates Wnt signaling in human osteoblasts through a positive feedback loop. J. Biol. Chem. 285, 25221-25231.

Ketting, R.F., Fischer, S.E., Bernstein, E., Sijen, T., Hannon, G.J., and Plasterk, R.H. (2001). Dicer functions in RNA interference and in synthesis of small RNA involved in developmental timing in C. elegans. Genes Dev. 15, 2654-2659.

Khvorova, A., Reynolds, A., and Jayasena, S.D. (2003). Functional siRNAs and miRNAs exhibit strand bias. Cell 115, 209-216.

Kim, N.V., and Jin-Wu, N. (2006). Genomics of microRNA. Trends Genet. 22, 165-173.

Kim, V.N., Han, J., and Siomi, M.C. (2009). Biogenesis of small RNAs in animals. Nat. Rev. Mol. Cell Biol. 10, 126139.

Kim, Y.J., Bae, S.W., Yu, S.S., Bae, Y.C., and Jung, J.S. (2009). miR-196a regulates proliferation and osteogenic differentiation in mesenchymal stem cells derived from human adipose tissue. J. Bone Miner. Res. 24, 816-825.

Kim,N.V. (2005). microRNA biogenesis: Coordinated cropping and dicing. Nat. Rev. Mol. Cell Biol. 6, 376-385.

Kloosterman, W.P., and Plasterk, R.H. (2006). The diverse functions of microRNAs in animal development and disease. Dev. Cell 11, 441-450.

Kwok, S., Partridge, N.C., Srinivasan, N., Nair, S.V., and Selvamurugan, N. (2009). Mitogen activated protein kinase-dependent inhibition of Osteoblast differentiation by Transforming Growth Factor-beta. J. Cell Biochem. 106, 161-169.

Lagos-Quintana, M., Rauhut, R., Lendeckel, W., and Tuschl, T. (2001). Identification of novel genes coding for small expressed RNAs. Science 294, 853-858.

Lee, I., Ajay, S.S., Yook, J.I., Kim, H.S., Hong, S.H., Kim, N.H., Dhanasekaran, S.M., Chinnaiyan, A.M., and Athey, B.D. (2009). New class of microRNA targets containing simultaneous 5'-UTR and 3'-UTR interaction sites. Genome Res. 19, 1175-1183.

Lee, M.H., Kwon, T.G., Park, H.S., Wozney, J.M., and Ryoo, H.M. (2003). BMP-2-induced Osterix expression is mediated by Dlx5 but is independent of Runx2. Biochem. Biophys. Res. Commun. 309, 689-694.

Lee, R.C., Feinbaum, R.L., and Ambros, V. (1993). The C. elegans heterochronic gene lin-4 encodes small RNAs with antisense complementarity to lin-14. Cell 75, 843854.

Lee, Y., Ahn, C., Han, J.J., Choi, H., Kim, J., Yim, J., Lee, J., Provost, P., Radmark, O., Kim, S., and Kim, V.N. (2003). The nuclear RNase III Drosha initiates microRNA processing. Nature 425, 415-419.

Lee, Y., Hur, I., Park, S.Y., Kim, Y.K., Suh, M.R., and Kim, 
V.N. (2006). The role of PACT in the RNA silencing pathway. EMBO J. 25, 522-532.

Lee, Y., Kim, M., Han, J., Yeom, K., Lee, S., Baek, S.H., and Kim, N.V. (2004). MicroRNA genes are transcribed by RNA polymerase II. EMBO J. 23, 4051-4060.

Lewis, B.P., Burge, C.B., and Bartel, D.P. (2005). Conserved seed pairing, often flanked by adenosines, indicates that thousands of human genes are microRNA targets. Cell 120, 15-20.

Li, H., Xie, H, Liu, W., Hu, R., Huang, B., Tan, Y.F., Xu, K., Sheng, Z.F., Zhou, H.D., Wu, X.P., and Luo, X.H. (2009). A novel microRNA targeting HDAC5 regulates osteoblast differentiation in mice and contributes to primary osteoporosis in humans. J. Clin. Invest. 119, 3666-3677.

Li, Z., Hassan, M.Q., Jafferji, M., Aqeilan, R.I., Garzon, R., Croce, C.M., van Wijnen, A.J., Stein, J.L., Stein, G.S., and Lian, J.B. (2009). Biological Functions of miR29b Contribute to Positive Regulation of Osteoblast Differentiation. J. Biol. Chem. 284, 15676-15684.

Li, Z., Hassan, M.Q., Volinia, S., van Wijnen, A.J., Stein, J.L., Croce, C.M., Lian, J.B., and Stein, G.S. (2008). A microRNA signature for a BMP2-induced osteoblast lineage commitment program. Proc. Natl. Acad. Sci. USA. 105, 13906-13911.

Lian, J.B., Stein, G.S., van Wijnen, A.J., Stein, J.L., Hassan, M.Q., Gaur T., and Zhang, Y. (2012). MicroRNA control of bone formation and homeostasis. Nat. Rev. Endocrinol. 8, 212-227.

Lin, G.L., and Hankenson, K.D. (2011). Integration of BMP, Wnt, and Notch signaling pathways in osteoblast differentiation. J. Cell Biochem. 112, 3491-3501.

Liu, Y., Liu, W., Hu, C., Xue, Z., Wang, G., Ding, B., Luo, H., Tang, L., Kong, X., Chen, X., Liu, N., Ding, Y., and Jin, Y. (2011). MiR-17 Modulates Osteogenic Differentiation Through a Coherent Feed-Forward Loop in Mesenchymal Stem Cells Isolated from Periodontal Ligaments of Patients with Periodontitis. Stem cells 29, 1804-1816.

Luzi, E., Marini, F., Sala, S.C., Tognarini, I., Galli, G., and Brandi, M.L. (2008). Osteogenic differentiation of human adipose tissue-derived stem cells is modulated by the miR-26a targeting of the SMAD1 transcription factor. J. Bone Miner. Res. 23, 287-295.

Lytle, J.R., Yario, T.A., and Steitz, J.A. (2007). Target mRNAs are repressed as efficiently by microRNA-binding sites in the 5' UTR as in the 3' UTR. Proc. Natl. Acad. Sci. USA. 104, 9667-9672.

Maeda, S., Hayashi, M., Komiya, S., Imamura, T., and Miyazono, K. (2004). Endogenous TGF-b signaling suppresses maturation of osteoblastic mesenchymal cells. EMBO J. 23, 552-563.

Mizuno, Y., Tokuzawa, Y., Ninomiya, Y., Yagi, K., YatsukaKanesaki, Y., Suda, T., Fukuda, T., Katagiri, T., Kondoh, Y., Amemiya, T., Tashiro, H., and Okazaki, Y. (2008). miR-210 promotes osteoblastic differentiation through inhibition of AcvR1b. FEBS Lett. 583, 2263-2268.

Mizuno, Y., Yagi, K., Tokuzawa, Y., Kanesaki-Yatsuka, Y., Suda, T., Katagiri, T., Fukuda, T., Maruyama, M., Okuda, A., Amemiya, T., Kondoh, Y., Tashiro, H., and Okazaki, Y. (2008). miR-125b inhibits osteoblastic differentiation by down-regulation of cell proliferation. Bioch. Biophy. Res. Comm. 368, 267-272.

Nilsen, T.W. (2007). Mechanisms of microRNA-mediated gene regulation in animal cells. Trends Genet. 23, 243249.

Noland, C.L., Ma, E., and Doudna, J.A. (2011). siRNA repositioning for guide strand selection by human Dicer complexes. Mol. Cell 43, 110-121.

Nottrott, S., Simard, M.J., and Richter, J.D. (2006). Human let-7a miRNA blocks protein production on actively translating polyribosomes. Nat. Struct. Mol. Biol. 13, 1108-1114.

Octacílio-Silva, S., Marques, M.M., Evangelista, A.F., Magalhaes, D.A., Dernowsek, J.A., Bombonato-Prado, K.F., Passos, G.A.S. (2010). Defining mRNA targets of microRNAs during osteoblastic differentiation of human mesenchymal stem cells by microarray transcriptional interaction networks. Resumos do $56^{\circ}$ Congresso Brasileiro de Genética. ISBN. 978-85-89109-06-2.1

Olsen, P.H., and Ambros, V. (1999). The lin-4 regulatory RNA controls developmental timing in Caenorhabditis elegans by blocking LIN-14 protein synthesis after the initiation of translation. Dev. Biol. 216, 671-680.

Oskowitz, A.Z., Lu, J., Penfornis, P., Ylostalo, J., McBride, J., Flemington, E.K., Prockop, D.J., and Pochampally, R. (2008). Human multipotent stromal cells from bone marrow and microRNA: regulation of differentiation and leukemia inhibitory factor expression. Proc. Natl. Acad. Sci. USA. 105, 18372-18377.

Ozsolak, F., Poling, L.L., Wang, Z., Liu, H., Liu, X.S., Roeder, R.G., Zhang, X., Song, J.S., and Fisher, D.E. (2008). Chromatin structure analyses identify miRNA promoters. Genes Dev. 22, 3172-3183.

Petersen, C.P., Bordeleau, M.E., Pelletier, J., and Sharp, P.A. (2006). Short RNAs repress translation after initiation in mammalian cells. Mol. Cell. 21, 533-542.

Pfeffer, S., Sewer, A., Lagos-Quintana, M., Sheridan, R., Sander, C., Grässer, F.A., van Dyk, L.F., Ho, C.K., Shuman, S., Chien, M., Russo, J.J., Ju, J., Randall, G., Lindenbach, B.D., Rice, C.M., Simon, V., Ho, D.D., Zavolan, M., and Tuschl, T. (2005). Identification of microRNAs of the herpesvirus family. Nat. Meth. 2, 269276.

Pillai, R.S. (2005). MicroRNA function: Multiple mechanisms for a tiny RNA?. RNA 11, 1753-1761.

Posrednik, D.V., Romanovskaia, T.V., Radishchevskaia, A.A., Khatskevich, A.A., Goncharevich, Alu, Cherepovich, V.S., and Grinev, V.V. (2011). Structural and thermodynamic features of intergenic and intronic human primary microRNAs. Mol. Biol. (Mosk). 45, 55-564.

Rodriguez, A., Griffiths-Jones, S., Ashurst, J.L, and Bradley, A. (2004). Identification of mammalian microRNA host genes and transcription units. Genome Res. 14, 19021910.

Ruby, J.G., Jan, C.H., and Bartel, D.P. (2007). Intronic microRNA precursors that bypass Drosha processing. Nature 448, 83-86.

Saini, H.K., Griffiths-Jones, S., and Enright, A.J. (2007). Genomic analysis of human microRNA transcripts. Proc. Natl. Acad. Sci. U S A. 104, 17719-17724.

Schoolmeesters, A., Eklund, T., Leake, D., Vermeulen, A., Smith, Q., Aldred, S.F., and Fedorov, Y. (2009). Functional Profiling Reveals Critical Role for miRNA in Differentiation of Human Mesenchymal Stem Cells. PLoS One 4, e5605.

Selbach, M., Schwanhausser, B., Thierfelder, N., Fang, Z., Khanin, R., and Rajewsky, N. (2008). Widespread 
changes in protein synthesis induced by microRNAs. Nature 455, 58-63.

Selvamurugan, N., Jefcoat, S.C., Kwok, S., Kowalewski, R., Tamasi, J.A., and Partridge, N.C. (2006). Overexpression of Runx2 Directed by the Matrix Metalloproteinase-13 Promoter Containing the AP-1 and Runx/RD/Cbfa Sites Alters Bone Remodeling In Vivo. J. Cell Biochem. 99, 545-557.

Shin, C., Nam, J.W., Farh, K.K., Chiang, H.R., Shkumatava, A., Bartel, D.P. (2010). Expanding the microRNA targeting code: functional sites with centered pairing. Mol. Cell. 38, 789-802.

Singh, S.K., Pal Bhadra, M., Girschick, H.J, and Bhadra, U. (2008). MicroRNAs - micro in size but macro in function. FEBS. 275, 4929-4944.

Taipaleenma"ki, H., Hokland, L.B., Chen, L., Kauppinen, S., and Kassem, M. (2012). MECHANISMS IN ENDOCRINOLOGY: Micro-RNAs: targets for enhancing osteoblast differentiation and bone formation. Eur. J. Endocrinol. 166, 359-371.

Tome, M., Lo'pez-Romero, P., Albo, C., Sepu' Iveda, J.C., Ferna'ndez-Gutie'rrez, B., Dopazo, A., Bernad, A., and Gonza' lez, M.A. (2011). miR-335 orchestrates cell proliferation, migration and differentiation in human mesenchymal stem cells. Cell Death Diff. 18, 985-995.

Treiber, T., Treiber, N., and Meister, G. (2012). Regulation of microRNA biogenesis and function. Thromb Haemost. 107.

Vasudevan, S., Tong, Y., and Steitz, J.A. (2007). Switching from repression to activation: microRNAs can upregulate translation. Science 318, 1931-1934.

Wahid, F., Shehzad, A., Khan, T., and Kim, Y.Y. (2010). MicroRNAs: synthesis, mechanism, function, and recent clinical trials. Biochim. Biophys. Acta. 1803, 1231-1243.

Wang, T., and Xu, Z. (2010). miR-27 promotes osteoblast differentiation by modulating Wnt signalling. Biochem. Biophys. Res. Commun. 402, 186-189.

Wells, S.E., Hillner, P.E., and Vale, R.D. (1998). Sachs AB. Circularization of mRNA by eukaryotic translation initiation factors. Mol. Cell. 2, 135-140.

Wienholds, E., Koudijs, M.J., van Eeden, F.J., Cuppen, E., and Plasterk, R.H. (2003). The microRNA-producing enzyme Dicer1 is essential for zebrafish development. Nat. Genet. 35, 217-218.

Winter, J., Jung, S., Keller, S., and Gregory, R.I. (2009). Diederichs $S$. Many roads to maturity: microRNA biogenesis pathways and their regulation. Nat. cell boil. 11, 228-234.

Yi, R., Qin, Y., Macara, I.G., and Cullen, B.R. (2003). Exportin-5 mediates the nuclear export of premicroRNAs and short hairpin RNAs. Genes Dev. 17, 3011-3016.

Yin, Q., Wang, X., Fewell, C., Cameron, J., Zhu, H., Baddoo, M., Lin, Z., and Flemington, E.K. (2010). MicroRNA miR155 inhibits bone morphogenetic protein (BMP) signaling and BMP-mediated Epstein-Barr virus reactivation. J. Virol. 84, 6318-6327.

Yuan, Z., Sun, X., Liu, H., and Xie, J. (2011). MicroRNA Genes Derived from Repetitive Elements and Expanded by Segmental Duplication Events in Mammalian Genomes. PLoS One 6, e17666.

Zeng, Y., and Cullen, B.R. (2004). Structural requirements for premicroRNA binding and nuclear export by Exportin 5. Nucleic Acids Res. 32, 4776-4785.

Zhang, J., Tu, Q., Bonewald, L.F., He, X., Stein, G., Lian, J., and Chen, J. (2011). Effects of miR-335-5p in modulating osteogenic differentiation by specifically downregulating Wnt antagonist DKK1. J. Bone Miner. Res. 26, 1953-63

Zhang, J.F., Fu, W.M., He, M.L., Wang, H., Wang, W.M., Yu, S.C., Bian, X.W., Zhou, J, Lin, M.C., Lu, G., Poon, W.S., and Kung, H.F. (2011). MiR-637 maintains the balance between adipocytes and osteoblasts by directly targeting Osterix. Mol. Biol. Cell. 22, 3955-3961.

Zhang, J.F., Fu, W.M., He, M.L., Xie, W.D., Lv, Q., Wan, G., Li, G., Wang, H., Lu, G., Hu, X., Jiang, S., Li, J.N., Lin, M.C., Zhang, Y.O., and Kung, H. (2011). MiRNA20 a promotes osteogenic differentiation of human mesenchymal stem cells by co-regulating BMP signalling. RNA biol. 8, 829-838.

Zhang, Y., Xie, R.L., Croce, C.M., Stein, J.L., Lian, J.B., van Wijnen, A.J., and Stein, G.S. (2011). A program of microRNAs controls osteogenic lineage progression by targeting transcription factor Runx2. Proc. Natl. Acad. Sci. USA. 108, 9863-9868. 


\section{Further Reading}

Caister Academic Press is a leading academic publisher of advanced texts in microbiology, molecular biology and medical research. Full details of all our publications at caister.com

- MALDI-TOF Mass Spectrometry in Microbiology Edited by: M Kostrzewa, S Schubert (2016) www.caister.com/malditof

- Aspergillus and Penicillium in the Post-genomic Era Edited by: RP Vries, IB Gelber, MR Andersen (2016) www.caister.com/aspergillus2

- The Bacteriocins: Current Knowledge and Future Prospects Edited by: RL Dorit, SM Roy, MA Riley (2016)

www.caister.com/bacteriocins

- Omics in Plant Disease Resistance Edited by: V Bhadauria (2016) www.caister.com/opd

- Acidophiles: Life in Extremely Acidic Environments Edited by: R Quatrini, DB Johnson (2016) www.caister.com/acidophiles

- Climate Change and Microbial Ecology: Current Research and Future Trend

Edited by: J Marxsen (2016)

www.caister.com/climate

- Biofilms in Bioremediation: Current Research and Emerging Technologies

Edited by: G Lear (2016)

www.caister.com/biorem

- Microalgae: Current Research and Applications Edited by: MN Tsaloglou (2016) www.caister.com/microalgae

- Gas Plasma Sterilization in Microbiology: Theory, Applications, Pitfalls and New Perspectives Edited by: H Shintani, A Sakudo (2016) www.caister.com/gasplasma

- Virus Evolution: Current Research and Future Directions Edited by: SC Weaver, M Denison, M Roossinck, et al. (2016) www.caister.com/virusevol

- Arboviruses: Molecular Biology, Evolution and Control Edited by: N Vasilakis, DJ Gubler (2016) www.caister.com/arbo

- Shigella: Molecular and Cellular Biology Edited by: WD Picking, WL Picking (2016) www.caister.com/shigella

-Aquatic Biofilms: Ecology, Water Quality and Wastewater Treatment

Edited by: AM Romaní, H Guasch, MD Balaguer (2016)

www.caister.com/aquaticbiofilms

- Alphaviruses: Current Biology

Edited by: S Mahalingam, L Herrero, B Herring (2016)

www.caister.com/alpha

- Thermophilic Microorganisms

Edited by: F Li (2015)

www.caister.com/thermophile
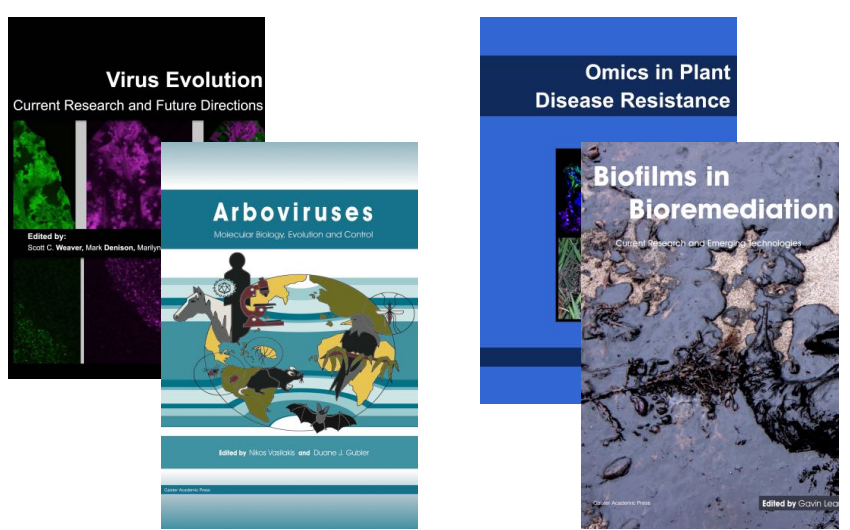
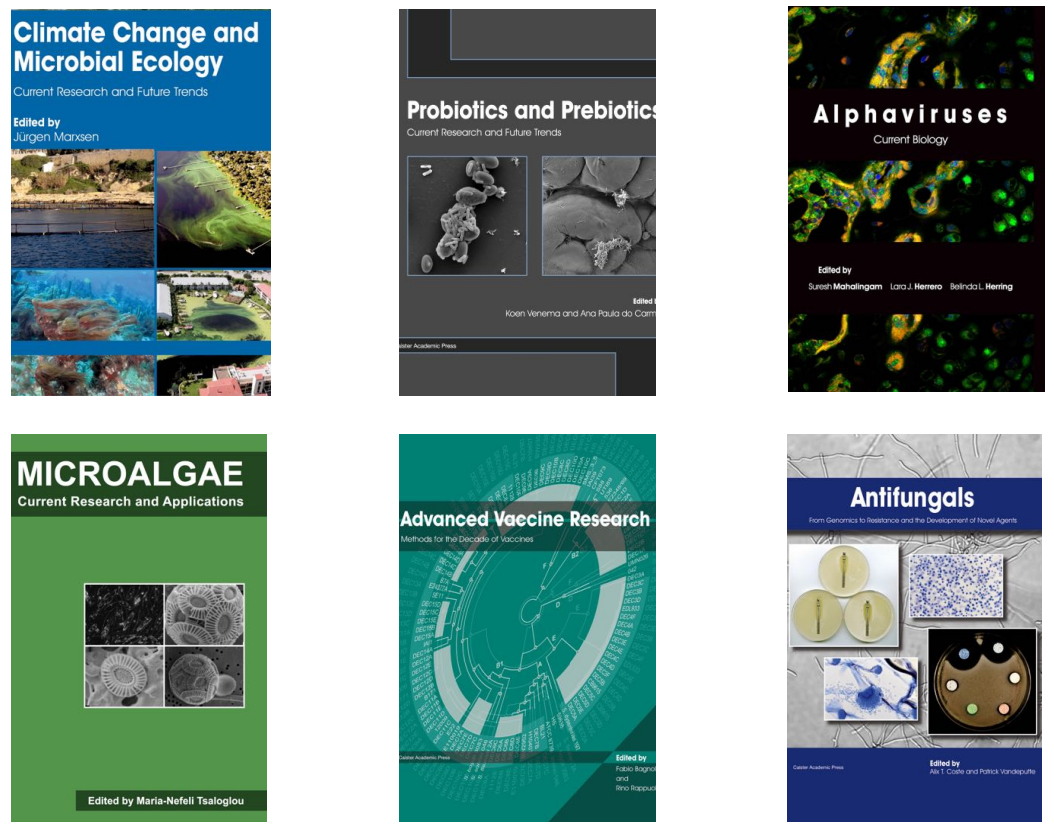

- Flow Cytometry in Microbiology: Technology and Applications Edited by: MG Wilkinson (2015) www.caister.com/flow

- Probiotics and Prebiotics: Current Research and Future Trends Edited by: K Venema, AP Carmo (2015) www.caister.com/probiotics

- Epigenetics: Current Research and Emerging Trends Edited by: BP Chadwick (2015) www.caister.com/epigenetics2015

- Corynebacterium glutamicum: From Systems Biology to Biotechnological Applications

Edited by: A Burkovski (2015)

www.caister.com/cory2

- Advanced Vaccine Research Methods for the Decade of Vaccines

Edited by: F Bagnoli, R Rappuoli (2015)

www.caister.com/vaccines

- Antifungals: From Genomics to Resistance and the Development of Novel Agents

Edited by: AT Coste, P Vandeputte (2015)

www.caister.com/antifungals

- Bacteria-Plant Interactions: Advanced Research and Future Trends Edited by: J Murillo, BA Vinatzer, RW Jackson, et al. (2015) www.caister.com/bacteria-plant

\section{- Aeromonas}

Edited by: J Graf (2015)

www.caister.com/aeromonas

- Antibiotics: Current Innovations and Future Trends

Edited by: S Sánchez, AL Demain (2015)

www.caister.com/antibiotics

- Leishmania: Current Biology and Contro Edited by: S Adak, R Datta (2015) www.caister.com/leish2

- Acanthamoeba: Biology and Pathogenesis (2nd edition) Author: NA Khan (2015)

www.caister.com/acanthamoeba2

- Microarrays: Current Technology, Innovations and Applications Edited by: Z He (2014)

www.caister.com/microarrays2

- Metagenomics of the Microbial Nitrogen Cycle: Theory, Methods and Applications

Edited by: D Marco (2014)

www.caister.com/n2 